\title{
Variant Brain-Derived Neurotrophic Factor (Val66Met) Alters Adult Olfactory Bulb Neurogenesis and Spontaneous Olfactory Discrimination
}

\author{
Kevin G. Bath, ${ }^{1}$ Nathalie Mandairon, ${ }^{5 *}$ Deqiang Jing, ${ }^{1 *}$ Rithwick Rajagopal, ${ }^{7,8,9}$ Ruchi Kapoor, ${ }^{1}$ Zhe-Yu Chen, ${ }^{10}$ \\ Tanvir Khan, ${ }^{1}$ Catia C. Proenca, ${ }^{1}$ Rosemary Kraemer, ${ }^{2}$ Thomas A. Cleland, ${ }^{6}$ Barbara L. Hempstead, ${ }^{4}$ Moses V. Chao, ${ }^{7,8,9}$ \\ and Francis S. Lee ${ }^{1,3}$ \\ Departments of ${ }^{1}$ Psychiatry, ${ }^{2}$ Pathology, ${ }^{3}$ Pharmacology, and ${ }^{4}$ Division of Hematology/Oncology, Department of Medicine, Weill Medical College of Cornell \\ University, New York, New York 10065, Departments of ${ }^{5}$ Neurobiology and Behavior and ${ }^{6}$ Psychology, Cornell University, Ithaca, New York 14853 , \\ Departments of ${ }^{7}$ Cell Biology, ${ }^{8}$ Physiology and Neuroscience, and ${ }^{9}$ Psychiatry, The Helen L. and Martin S. Kimmel Center for Biology and Medicine \\ at the Skirball Institute for Biomolecular Medicine, New York University School of Medicine, New York, New York 10016, and ${ }^{10}$ Department of \\ Neurobiology, School of Medicine, Shandong University, Jinan, Shandong 250012, People's Republic of China
}

Neurogenesis, the division, migration, and differentiation of new neurons, occurs throughout life. Brain derived neurotrophic factor (BDNF) has been identified as a potential signaling molecule regulating neurogenesis in the subventricular zone (SVZ), but its functional consequences in vivo have not been well defined. We report marked and unexpected deficits in survival but not proliferation of newly born cells of adult knock-in mice containing a variant form of BDNF [a valine (Val) to methionine (Met) substitution at position 66 in the prodomain of BDNF (Val66Met)], a genetic mutation shown to lead to a selective impairment in activity-dependent BDNF secretion. Utilizing knock-out mouse lines, we identified BDNF and tyrosine receptor kinase B (TrkB) as the critical molecules for the observed impairments in neurogenesis, with p75 knock-out mice showing no effect on cell proliferation or survival. We then localized the activated form of TrkB to a discrete population of cells, type A migrating neuroblasts, and demonstrate a decrease in TrkB phosphorylation in the SVZ of Val66Met mutant mice. With these findings, we identify TrkB signaling, potentially through activity dependent release of BDNF, as a critical step in the survival of migrating neuroblasts. Utilizing a behavioral task shown to be sensitive to disruptions in olfactory bulb neurogenesis, we identified specific impairments in spontaneous olfactory discrimination, but not general olfactory sensitivity or habituation to olfactory stimuli in BDNF mutant mice. Through these observations, we have identified novel links between genetic variant BDNF and adult neurogenesis in vivo, which may contribute to significant impairments in olfactory function.

Key words: neurogenesis; olfaction; BDNF; TrkB; Val66Met; SVZ

\section{Introduction}

Granule cells of the olfactory bulb (OB) are continuously replaced throughout the lifespan from neural stem cells located in the subventricular zone (SVZ) of the lateral ventricle (Altman, 1969). The incorporation of new cells occurs in an odor-specific, learning-dependent manner (Alonso et al., 2006; Mandairon et al., 2006b), suggesting that the influence of granule cell activity on mitral cell odor representations is in turn regulated by the selec-

Received Sept. 25, 2007; revised Jan. 19, 2008; accepted Jan. 19, 2008.

This work was supported by the Sackler Institute (K.G.B., F.S.L.), DeWitt-Wallace Fund of the New York Community Trust (F.S.L.), National Alliance for Research on Schizophrenia and Depression (F.S.L., Z.-Y.C.), National Institutes of Health Grants MH060478 (K.G.B.), NS30687 (B.L.H.), NS21072 (M.V.C.), HD23315 (M.V.C.), NS052819 (F.S.L.), and MH068850 (F.S.L.), National Natural Science Foundation of China Grants 30671050 and 30725020, and the National Key Basic Research Program of China (973 program, 2006CB503803). We thank Stewart Anderson, Daniel Herrera, Alessandro leraci, and Kenneth Teng for helpful discussions.

*N.M. and D.J. contributed equally to this work.

Correspondence should be addressed to either Francis S. Lee or Kevin G. Bath, Department of Psychiatry, Weill Medical College of Cornell University, LC-903a, 1300 York Avenue, New York, NY 10021. E-mail: fslee@med.cornell.edu. or kgb2001@med.cornell.edu.

DOI:10.1523/JNEUROSCI.4387-07.2008

Copyright $\odot 2008$ Society for Neuroscience $\quad$ 0270-6474/08/282383-11\$15.00/0 tive survival and differentiation of these migrating neuroblasts. Indeed, low rates of neurogenesis have been linked to impairments in olfactory discrimination (Gheusi et al., 2000; Mandairon et al., 2006b). The signaling molecules that modulate cell migration and survival are not well understood. In this context, the $\mathrm{OB}$ provides a model system for examining the signaling molecules that regulate neurogenesis and the functional importance of newly born neurons.

Mechanisms involving diffusible signaling molecules, such as neurotransmitters, neuropeptides, and growth factors, have been proposed to regulate olfactory bulb neurogenesis (Lledo and Saghatelyan, 2005). One growth factor that has been implicated in adult neurogenesis is brain-derived neurotrophic factor (BDNF). In explant cell cultures, BDNF is critical for the survival and migration of newly dividing cells (Kirschenbaum and Goldman, 1995; Chiaramello et al., 2007). The overexpression or direct administration of BDNF into the lateral ventricles increases cell migration into structures adjacent to the lateral ventricles and OB (Zigova et al., 1998; Benraiss et al., 2001; Pencea et al., 2001). Despite the demonstration that exogenous BDNF can influence 
adult neurogenesis and the survival of SVZ-derived cells in culture, the role of endogenous BDNF signaling in neurogenic populations remains unclear. Furthermore, BDNF can signal via tyrosine receptor kinase $\mathrm{B}(\mathrm{TrkB})$ or $\mathrm{p} 75$ receptors, both of which are expressed in the SVZ of adult animals (Zigova et al., 1998; Giuliani et al., 2004) and have been identified in in vitro studies as potential regulators of neuroblast migration or survival (Chiaramello et al., 2007; Young et al., 2007). However, which receptor is responsible for the observed BDNF-mediated effects on neurogenesis in vivo is unclear. Despite the likely functional significance of BDNF and its receptors for adult $\mathrm{OB}$ neurogenesis, no studies have assessed the functional consequences of disruption in BDNF signaling on olfactory behavior. Additionally, the previous discovery of a uniquely human single-nucleotide polymorphism (SNP) in the $b d n f$ gene [a valine (Val) to methionine (Met) substitution at position 66 in the prodomain of BDNF (Val66Met)], and the generation of a mouse model of this SNP (Chen et al., 2006), has provided a valuable tool to assess potential consequences of altered BDNF signaling to human populations.

We report here that disruption of the BDNF-TrkB pathway, but not p75, results in impairments in survival but not proliferation of newly born cells. Phosphorylated TrkB was localized to migrating neuroblasts (type A cells), linking TrkB activation to the survival of migrating neuroblasts. Moreover, we observed a discrete and new defect in spontaneous olfactory discrimination behavior in BDNF heterozygous, TrkB heterozygous, and Val66Met mice, linking impairments in activity-dependent secretion of BDNF to the migration and survival of newly born cells in the adult olfactory bulb with implications for behavioral outcomes on olfactory sensory function.

\section{Materials and Methods}

\section{Genetically modified neurotrophin and neurotrophin} receptor mice

TrkB receptor haploinsufficient mice $\left(\operatorname{TrkB}^{+/-}\right)$(Xu et al., 2000), heterozygous BDNF $\left(\mathrm{BDNF}^{+/-}\right.$) (Ernfors et al., 1994), p75 knockout $\left(\mathrm{p} 75^{-1-}\right)$ (Lee et al., 1992), and BDNF Val66Met knock-in $\left(\right.$ BDNF $^{\text {Met/Met }}$ ) mice (Chen et al., 2006) were all maintained on an inbred C57BL/6 background. All studies were performed in 8- to 10-week-old adult mice. Animal care was in accordance with Weill Medical College of Cornell University Institutional Animal Care and Use Committee and Food and Drug Administration standards.

\section{Tissue preparation and immunohistological analyses}

Control and genetically modified lines of mice were deeply anesthetized with pentobarbital and transcardially perfused with a solution of $0.9 \%$ saline and $0.1 \%$ sodium nitrite followed by $4 \%$ paraformaldehyde in phosphate buffer (PB). Brains were dissected out and postfixed in $4 \%$ paraformadehyde for $1 \mathrm{~h}$. Brains were then incubated in a 30\% sucrose solution overnight at $4^{\circ} \mathrm{C}$. Coronal sections were serially cut at $40 \mu \mathrm{m}$ using a freezing microtome. Immunohistochemistry was performed on floating sections. Briefly, sections were first incubated in a blocking solution for $1 \mathrm{~h}$ and then transferred to the primary antibody solution for $48 \mathrm{~h}$ at $4^{\circ} \mathrm{C}$ before incubation with the corresponding fluorescent-labeled (Invitrogen, Carlsbad, CA) or biotinylated secondary antibody (Vector Laboratories, Burlingame, CA). Antibodies and dilutions used included a rabbit polyclonal anti-pTrkB (1:500), anti-NeuN (Millipore; 1:1000), anti-polysialylated neural cell adhesion molecule (PSA-NCAM; Millipore; 1:400), anti-Nestin (Millipore; 1:200), anti-doublecortin (DCX; Millipore; 1:1000), anti-GFAP (Millipore; 1:1000), anti-Ki-67 (BD PharMingen, San Diego, CA; 1:200), anti-p75 (R\&D Systems, Minneapolis, MN; 1:100), biotinylated isolectin B-4 (Vector Laboratories; 1:150), anti-BDNF (Sigma, St. Louis, MO; 1:100). Certain sections were analyzed using a standard Nikon (Tokyo, Japan) upright microscope, digital camera mount, and the MetaMorph software package (Molecular Devices, Sunnyvale, CA). In addition, confocal fluorescence microscopy was performed using a Zeiss (Oberkochen, Germany) LSM510 microscope fitted with a Zeiss $63 \times 1.4$ numerical aperture $(\mathrm{NA})$ objective with standard filter sets and a standard (1 Airy disk) pinhole.

\section{BrdU labeling and detection}

To quantify adult neurogenesis, 5-bromo-2'-deoxyuridine (BrdU; Sigma), a marker taken up during DNA synthesis, was administered via intraperitoneal injection in mice between the ages of postnatal day 60 and $90(150 \mathrm{mg} / \mathrm{kg}$ of body weight in $0.9 \% \mathrm{NaCl})$. Animals were perfused either $2 \mathrm{~h}$ or $28 \mathrm{~d}$ after BrdU injection to track proliferation or survival of neurogenic cells, respectively. Brains were sectioned on a freezing microtome and then processed for immunohistochemistry. To denature DNA, sections were treated for $20 \mathrm{~min}$ at room temperature followed by $20 \mathrm{~min}$ at $37^{\circ} \mathrm{C}$ with $2 \mathrm{M} \mathrm{HCl}$ in PB. Tissue was then washed in sodium borate buffer for $10 \mathrm{~min}(0.1 \mathrm{M}, \mathrm{pH} 8.5)$, and then rinsed with $0.1 \mathrm{M}$ PBS before blocking and subsequent incubation with anti-BrdU antibody (for single labeling, mouse anti-BrdU, 1:100, BD, Franklin Lakes, NJ; for double labeling with mouse anti-NeuN, 1:1000, Millipore; rat anti-BrdU, 1:100, Dako, High Wycombe, UK). The anti-BrdU antibody was then revealed either with a biotinylated secondary (goat anti-mouse 1:200; Vector Laboratories), ABC (Vector Laboratories; ABC Elite kit), and $\mathrm{DAB}$ peroxidase method (DAB tablet set; Sigma), or a corresponding fluorescent-labeled secondary antibody (Alexa-conjugated goat anti-rat 488, Invitrogen; or Alexa-conjugated goat anti-mouse 594, Invitrogen). Only immunopositive nuclei were counted.

\section{BrdU quantitative analyses}

To quantify the density of BrdU-positive cells in the granule cell layer of the olfactory bulb, an optical fractionator method was used. Every third serially obtained section ( $80 \mu \mathrm{m}$ interval) was mounted and processed immunohistochemically to detect BrdU. Sections were counterstained with Nissl and a reference volume of the granule cell layer was traced using a stereology system (Stereoinvestigator; MicroBrightField, Williston, VT). BrdU-positive nuclei were counted within a $20 \times 20 \times 30 \mu \mathrm{m}$ counting frame, which randomly sampled within a $122.8 \times 68.9 \mu \mathrm{m}$ randomized counting grid using a meander scanning technique. BrdUpositive cells throughout the $z$-plane were counted; those that contacted the lateral or upper exclusion plane remained uncounted. The total number of cells counted were divided into the number of counting frames sampled multiplied by the size of the counting frame to obtain an estimate of the density of BrdU-positive cells within this structure.

To quantify the density of BrdU-positive cells in the SVZ we used a linear counting method. Again, every third serially obtained section ( 80 $\mu \mathrm{m}$ interval) was mounted and processed immunohistochemically to detect BrdU. Sections were counterstained with Nissl and a reference line was drawn at the boundary between the SVZ and the ependymal cell layer lining the lateral ventricles using a stereology system (Stereoinvestigator; MicroBrightField). Coronal sections from approximately Bregma (1.54 $\mathrm{mm})$ to bregma $(0.74 \mathrm{~mm})$ were sampled. All BrdU-positive nuclei within $100 \mu \mathrm{m}$ of this boundary line were exhaustively counted. Because the boundary between the SVZ and striatum is often unclear, we divided the total number of cells into the length of the boundary line to obtain a linear density of BrdU-positive cells.

\section{Generation of antibodies against phosphorylated TrkB receptors}

A peptide (LQNLAKASPVPYLDILG) containing phosphorylated tyrosine 816 of rat TrkB, shown previously to be a site for phospholipase C- $\gamma$ (PLC- $\gamma$ ) recruitment in response to BDNF (Rajagopal et al., 2004) was used to immunize rabbits. Crude serum was first passed through an affinity column made by coupling the nonphosphorylated version of the peptide to cyanogen bromide-activated Sepharose beads. Flow through from this column was then passed through a column made by coupling the phosphopeptide to cyanogen bromide-activated Sepharose. The column was washed extensively with Tris-buffered saline containing $0.1 \%$ Tween 20, and antibodies were then eluted with $0.1 \mathrm{M}$ glycine, $\mathrm{pH} 2.5$. Fractions were collected from the eluate, neutralized with Tris buffer, $\mathrm{pH}$ 9.5, and then tested for specificity by blotting BDNF-treated 293-TrkB cell lysates. Specificity was further confirmed by a peptide competition assay in which a fivefold weight excess of phosphorylated TrkB peptide 
was preincubated with antibody for $2 \mathrm{~h}$ at $4^{\circ} \mathrm{C}$ and then used for Western blotting.

\section{ELISA}

For BDNF protein measurements in brain lysates, tissues of interest were dissected and then homogenized and lysed in $10 \mathrm{~mm}$ Tris, $\mathrm{pH} 7.5,150 \mathrm{~mm}$ $\mathrm{NaCl}, 1 \mathrm{~mm}$ EDTA, and $0.5 \% \mathrm{NP}-40$ with protease and phosphatase inhibitors. After homogenation and lysis, the lysates were centrifuged and the supernatant was collected. Total protein concentrations in these lysates were then measured using the Bradford protein concentration assay, with standards and samples all being assayed in triplicate. BDNF protein concentrations for respective brain regions were determined using the BDNF Emax immunoassay system with recombinant mature BDNF as a standard. This ELISA is based on an antibody to the C-terminal region of BDNF and may also recognize proBDNF. Standards were performed in duplicates and samples in triplicates, with each group containing five independent samples. All measurements were corrected for the total amount of protein loaded.

\section{Immunoprecipitation and immunoblotting}

For dissection of SVZ tissue, postnatal day 60 wild-type (WT) and $\mathrm{BDNF}^{\mathrm{Met} / \mathrm{Met}}$ mice were anesthetized and then decapitated. The brain was dissected out and moved to a $6 \%$ glucose solution on ice. Olfactory bulbs were removed and the brain was blocked at bregma 0.0. Using dissecting scissors, a thin layer of tissue was removed from the lateral wall of the lateral ventricle and frozen at $-80^{\circ} \mathrm{C}$. SVZ extracts were then homogenized and lysed in $10 \mathrm{~mm}$ Tris, $\mathrm{pH} 7.5,150 \mathrm{~mm} \mathrm{NaCl}, 1 \mathrm{~mm}$ EDTA, and $0.5 \%$ NP-40 with protease and phosphatase inhibitors. After centrifugation, lysates were incubated with anti-panTrk polyclonal antibody (Santa Cruz Biotechnology, Santa Cruz, CA). The immunocomplex was precipitated using protein A-Sepharose beads and then boiled in SDS-sample buffer and loaded on SDS-PAGE gels for immunoblot analysis with anti-pTrkB antibodies. The immunoreactive protein bands were detected by enhanced chemiluminescence (Thermo-Scientific, Rockford, IL). The membranes were then stripped and reprobed with TrkB antibody (Upstate Biotechnology, Lake Placid, NY). The intensity of the Western blot bands were quantified using Image J software. The TrkB phosphorylation level was normalized by the pTrkB/total TrkB ratio.

\section{Neuronal cell cultures}

Dissociated primary cultures of hippocampal neurons from embryonic day 18 (E18) rats were prepared from timed-pregnant Sprague Dawley rats, as described previously (Lee and Chao, 2001). Briefly, fetuses were removed under sterile conditions and kept in PBS on ice for microscopic dissection of the hippocampi. The meninges were removed and the tissue was placed in Neurobasal media (Invitrogen). The tissue was briefly minced with fine forceps and then triturated with a fire-polished Pasteur pipette. Cells were counted and plated on culture wells coated with 0.01 $\mathrm{mg} / \mathrm{ml}$ poly-D-lysine overnight in a Neurobasal medium containing B27 supplement (Invitrogen) and L-glutamine (0.5 mM) (Invitrogen). Experiments were conducted $3-4 \mathrm{~d}$ after plating.

\section{Confocal imaging}

Confocal fluorescence microscopy was performed using a Zeiss LSM510 microscope fitted with a Zeiss $63 \times 1.4$ NA objective with standard filter sets and a standard (1 Airy disk) pinhole. Images selected for publication were exported from LSM software into PhotoShop CS (Adobe Systems, San Jose, CA).

\section{Olfactory cross-habituation task (spontaneous discrimination)}

Odor sets. Five odor sets of four odorants each were used for the crosshabituation experiments used to measure spontaneous discrimination (supplemental Table 1, available at www.jneurosci.org as supplemental material). All odorants were diluted in mineral oil so as to theoretically emit a steady-state vapor phase partial pressure of $0.01 \mathrm{~Pa}$ (Cleland et al., 2002); corresponding volume/volume dilutions are listed in supplemental Table 1 (available at www.jneurosci.org as supplemental material). Each odor set consisted of a homologous series of three unbranched aliphatic molecules $\left(\mathrm{O}_{\text {hab }}, \mathrm{S} 1, \mathrm{~S} 2\right)$ and a dissimilar control odorant (D).
In each set, odorants were selected so that the most similar odorant, S1, had a chain length that differed by one carbon atom from the habituation odorant $\mathrm{O}_{\text {hab }}$, the moderately similar odorant $\mathrm{S} 2$ differed from $\mathrm{O}_{\text {hab }}$ by two carbon atoms, and odorant $\mathrm{D}$ was structurally and perceptually dissimilar to all of the others. At the odorant concentration used, perceptual similarity correlates with structural similarity within straight-chain aliphatic series (Cleland et al., 2002; Cleland and Narla, 2003).

Behavioral testing. Male mice, 6-8 weeks of age, were used for crosshabituation testing. Mice of different genotypes within each of the three behavioral cohorts $\left(\mathrm{BDNF}^{+1-}, \mathrm{TrkB}^{+/-}\right.$, and BDNF Val66Met knockin) were littermates. No conditioning or food deprivation was performed before this study.

An olfactory cross-habituation task assesses the degree to which mice spontaneously discriminate odorants by habituating them to one odorant $\left(\mathrm{O}_{\text {hab }}\right)$ and then measuring the magnitude of their novelty response to other odorants (strongly similar S1, moderately similar S2, and dissimilar D). Presentation of a novel odorant will elicit substantial investigation of the new stimulus; however, if the second odorant is perceived as similar to the habituated odorant (i.e., if it is cross-habituated), the mouse will spend correspondingly less time investigating the second odorant when it is presented. Because no reward is associated with either odorant in this task, and each test odor is presented only once, this task is used to measure baseline perceptual similarities between odorants, unaltered by a history of reinforcement. Odors were presented by placing 60 $\mu \mathrm{l}$ of the diluted odor stimulus onto a filter paper disc (\#1; Whatman, Florham Park, NJ) contained within a tea ball that was placed in the cage. Each test session was preceded by one $50 \mathrm{~s}$ presentation of plain mineral oil. Test sessions comprised four $50 \mathrm{~s}$ presentations of the habituation odorant $\left(\mathrm{O}_{\text {hab }}\right)$ at $5 \mathrm{~min}$ intervals, followed by one $50 \mathrm{~s}$ presentation of each of the test odorants (S1, S2, and D) in a randomized and counterbalanced order. The amount of time that the mice spent actively investigating each presented odorant was measured. Active investigation was defined as directed sniffing within $1 \mathrm{~cm}$ of the odor source. Behavioral testing was repeated over $5 \mathrm{~d}$ using five different odor sets; all data were averaged within subjects. Time spent sniffing was coded during testing, with the experimenter blind to odorant identity as well as the genotype of mice.

\section{Statistical analysis}

For behavioral testing, statistical analyses were performed on the times spent sniffing during odor presentation trials. First, the effects on habituation to repeated presentations of the same odorant were assessed. A multivariate, repeated-measures ANOVA with post hoc multiple comparisons [Tukey's honestly significant difference (HSD)] was performed with the habituation trial number as within-subjects factor and genotype (heterozygous BDNF or wild-type in the first study, TrkB heterozygous and wild-type mice for the second study, and $\mathrm{BDNF}^{+/+}, \mathrm{BDNF}^{+/ \mathrm{Met}}$, or $\mathrm{BDNF}^{\mathrm{Met} / \mathrm{Met}}$ at codon 66 in the third study) as a between-subjects factor. Simple effects analysis with multiple comparisons was then performed to separately assess the effects for each genotype. Next, the effects on crosshabituation, or spontaneous discrimination among odorants, were assessed using the same methodology, but with dissimilarity as the withinsubjects factor. Analyses were made using SPSS 14.0 software (SPSS, Chicago, IL) with a significance level of $\alpha=0.05$.

For neurogenesis assays, statistical analyses were performed on the raw mean density of cells for each region sampled. Overall effects of genotype were assessed either with a Student's $t$ test (in the case of two genotypes), or using a one-way ANOVA with post hoc multiple comparisons (Tukey's HSD) with genotype as the between-subjects factor. Analyses were made using SPSS software with a significance level of $\alpha=0.05$.

\section{Results \\ Haploinsufficiency of BDNF results in decreased survival but not proliferation}

As BDNF has been identified as a potential molecule that may function in regulating neurogenesis in the adult brain, we first tested the impact of altered BDNF levels on cell proliferation and survival in the SVZ and OB. Haploinsufficient BDNF $\left(\mathrm{BDNF}^{+/-}\right)$and wild-type $\left(\mathrm{BDNF}^{+/+}\right)$mice were injected with a 
a

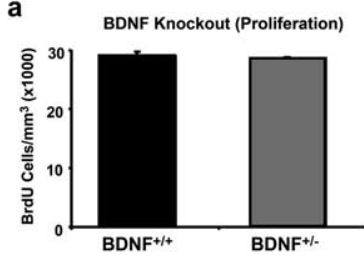

d

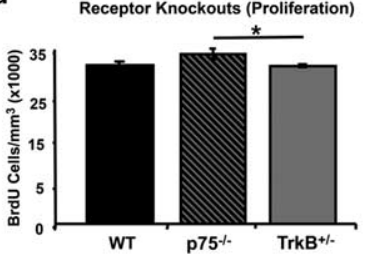

f

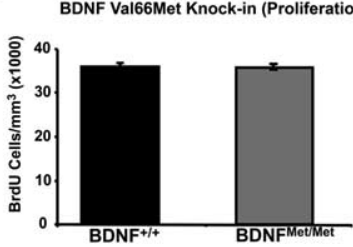

b

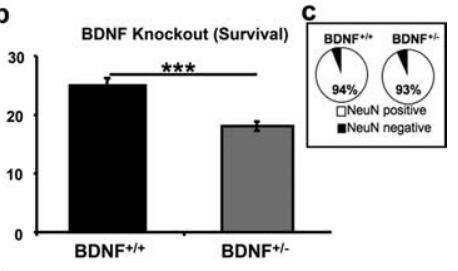

e

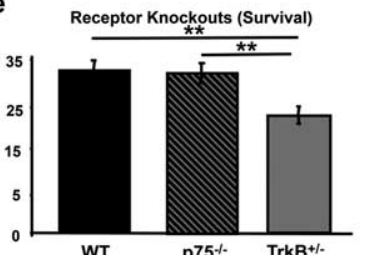

g

BDNF Val66Met Knock-in (Survival)

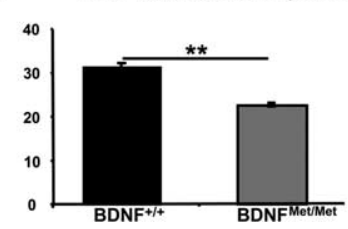

Figure 1. Loss of BDNF signaling via TrkB impacts the survival but not proliferation of neuroblasts. $\boldsymbol{a}, \boldsymbol{b}$, Quantification of the density of BrdU-labeled cells in the SVZ (a) counted $2 \mathrm{~h}$ after BrdU administration (BDNF ${ }^{+/+}, n=4$; BNDF ${ }^{+/-}, n=4$ ) and the granule cell layer of the $\mathrm{OB}(\mathrm{gcOB})(\boldsymbol{b})$ counted $28 \mathrm{~d}$ after BrdU administration $\left(\mathrm{BDNF}^{+/+}, n=4 ; \mathrm{BDNF}^{+/-}, n=\right.$ 4). c, Quantification of the percentage of overlap between BrdU-positive and NeuN-positive immunofluorescent double labeling in the gcOB from mice $28 \mathrm{~d}$ after injection $(n=820$ cells from 8 mice). Data are presented as the percentage of double-labeled cells for BDNF ${ }^{+/+}$and $\mathrm{BDNF}^{+/-}$mice. $\boldsymbol{d}, \boldsymbol{e}$, Quantification of BrdU cell density in the ( $\left.\boldsymbol{d}\right)$ SVZ of wild-type $(n=8)$, p75 knock-out (p75 $-1-, n=4$ ), and TrkB heterozygous (TrkB ${ }^{+/-}, n=4$ ) mice $2 \mathrm{~h}$ after BrdU administration and (e) BrdU cell density in the gcOB $28 \mathrm{~d}$ after BrdU injection (WT, $n=4$; p75 $\left.{ }^{-I-}, n=4 ; \mathrm{TrkB}^{+/-}, n=4\right) . \boldsymbol{f}, \boldsymbol{g}$, Quantification of the density of BrdU-positive cells in BDNF Val66Met knock-in mice $(\boldsymbol{f})$ in the SVZ $2 \mathrm{~h}$ after BrdU administration (BDNF ${ }^{+/+}, n=4$ and BDNF $\left.{ }^{\text {Met/Met }}, n=4\right)$ or $(\boldsymbol{g})$ or in the gcOB $28 \mathrm{~d}$ after BrdU administration (BDNF ${ }^{+/+}, n=$ 6 and BDNF ${ }^{\text {Met } / \text { Met }}, n=6$ ). Asterisks indicate statistically significant difference: ${ }^{*} p<0.05$; ${ }^{* *} p<0.01 ;{ }^{* * *} p<0.001$. Error bars depict the SEM.

single $150 \mathrm{mg} / \mathrm{kg}$ pulse of BrdU. BrdU, a thymidine analog, is incorporated into the DNA of cells during the S-phase of cell division for a period of $\sim 2 \mathrm{~h}$ after injection. Mice were then perfused either $2 \mathrm{~h}$ (proliferation) or $28 \mathrm{~d}$ (survival) after injection, and BrdU incorporation was assessed using immunohistochemical labeling.

We found no impact of BDNF haploinsufficiency on proliferation rates in the SVZ of adult mice (Student's $t$ test, $t_{(6)}=0.712$, $p>0.05$ ), with the density of BrdU-positive cells in the SVZ being nearly identical in $\mathrm{BDNF}^{+/+}$and $\mathrm{BDNF}^{+/-}$mice (Fig. 1a). We did, however, find a significant effect of genotype for cell survival, with $\mathrm{BDNF}^{+/-}$mice having a significant decrease in the density of BrdU-positive cells in the granule cell layer of the OB compared with control mice at $28 \mathrm{~d}$ after injection (Student's $t$ test, $\left.t_{(10)}=5.115, p<0.001\right)($ Fig. $1 b)$.

To assess the impact of BDNF haploinsufficiency on rates of cell differentiation into a neuronal phenotype, double labeling was performed with BrdU and NeuN, a marker of neuronal nuclei. We found no main effect of genotype for the percentage of colocalization (Student's $t$ test, $t_{(6)}=2.003, p>0.05$ ), with $\mathrm{BDNF}^{+/+}$mice having an equivalent percentage of NeuN-BrdU double-labeled cells as $\mathrm{BDNF}^{+/-}$mice (94 and 93\%, respectively) (Fig. 1c).

TrkB receptors, not $\mathrm{p} 75$ receptors, are critical for $\mathrm{OB}$ neurogenesis

BDNF is known to signal through two classes of receptor systems, TrkB receptors and p75 receptors (Chao, 2003). In previous in vitro studies, both classes of receptors have been identified as potentially playing a role in adult neurogenesis (Chiaramello et al., 2007; Young et al., 2007). To assess the relative contributions of TrkB and p75 receptors to the proliferation and survival of newly born cells, we assayed the density of BrdU labeled cells in the SVZ and $\mathrm{OB}$ of TrkB receptor haploinsufficient mice $\left(\operatorname{TrkB}{ }^{+/-}\right)$and $\mathrm{p} 75$ knock-out mice $\left(\mathrm{p} 75^{-1-}\right)$ either $2 \mathrm{~h}$ (proliferation) or $28 \mathrm{~d}$ (survival) after a single $150 \mathrm{mg} / \mathrm{kg}$ intraperitoneal injection of BrdU. A significant main effect of genotype on cell proliferation was found (ANOVA, $F_{(2,13)}=4.821, p<0.027$ ). Post hoc multiple comparisons further showed that p75 null mice have significantly higher rates of cell proliferation than do TrkB heterozygotes (Tukey HSD, $p<0.01$ ), however, neither p75 null (Tukey HSD, $p>0.05$ ) or TrkB heterozygotes (Tukey HSD, $p>$ $0.05)$ significantly differed from WT levels of cell proliferation (Fig. 1d). A significant main effect of genotype on cell survival was also observed (ANOVA, $F_{(2,9)}=31.963, p<0.001$ ) with TrkB heterozygotes having significantly fewer surviving cells compared with either wild-type (Tukey HSD, $p<0.05$ ) or p75 null (Tukey HSD, $p>0.05$ ) mice (Fig. 1e). Specifically, TrkB heterozygotes had a nearly $30 \%$ reduction in the density of surviving BrdU-positive cells in the granule cell layer of the $\mathrm{OB}$ compared with wild-type controls, whereas p75 null mice had nearly identical levels of surviving BrdU-positive cells relative to wild-type mice.

\section{Impaired activity-dependent BDNF secretion leads to impaired OB neurogenesis}

To determine the molecular basis for the ability of BDNF to alter the rate of survival of newly born granule cells, we conducted a series of experiments to examine the impact of impaired activitydependent secretion of BDNF on neurogenesis. We used a recently generated knock-in mouse with a selective deficit in activity-dependent BDNF secretion (Chen et al., 2006). In this mouse, a variant BDNF with a valine (Val) to methionine (Met) substitution at position 66 in the prodomain of BDNF (Val66Met) replaced the wild-type BDNF allele. This polymorphism results in an $\sim 30 \%$ decrease in the activity-dependent secretion of BDNF but has no impact on total BDNF levels or constitutive secretion (Chen et al., 2006). First, we injected control mice and mice with two copies of the BDNF Met allele $\left(B D N F{ }^{\text {Met/Met }}\right.$ ) with a single $150 \mathrm{mg} / \mathrm{kg}$ pulse of BrdU and killed the animals either $2 \mathrm{~h}$ or $28 \mathrm{~d}$ after injection. We found no effect of genotype on the density of proliferating cells within the SVZ of adult mice (Student's $t$ test, $t_{(6)}=0.095, p>0.05$ ) (Fig. $1 f$ ). When comparing the density of surviving BrdU-positive cells in the granule cell layer of the $\mathrm{OB}$, we found a significant main effect of genotype (Student's $t$ test, $t_{(10)}=8.044, p<0.001$ ) (Fig. $1 g$ ) with $\mathrm{BDNF}^{\text {Met/Met }}$ mice having significantly fewer BrdU-positive cells in the OB compared with WT controls.

\section{Altered BDNF-TrkB signaling leads to regional alterations in neuronal and neuroblast survival}

Previous studies have shown that BDNF both acts as a chemotactic agent and influences cell migration within the developing brain (Borghesani et al., 2002; Fukumitsu et al., 2006). To assess whether its established effects on cell survival occur in a region specific manner that would suggest a migratory impairment, we plotted the density of surviving BrdU-positive cells as a function 
a

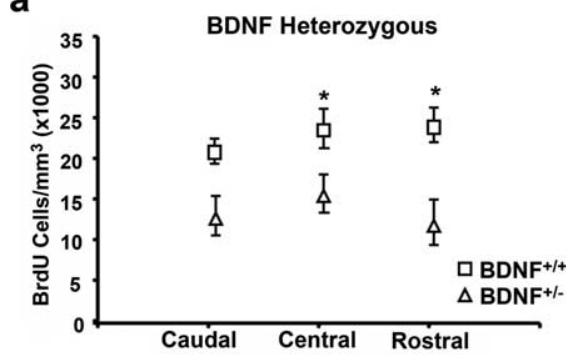

c

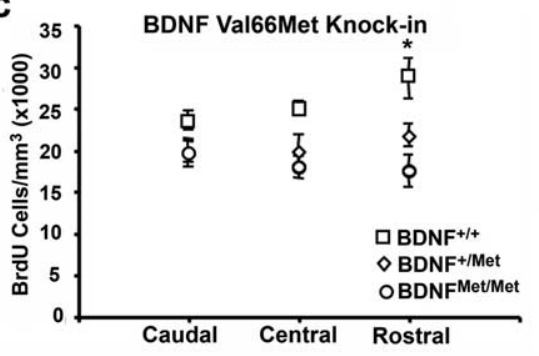

b

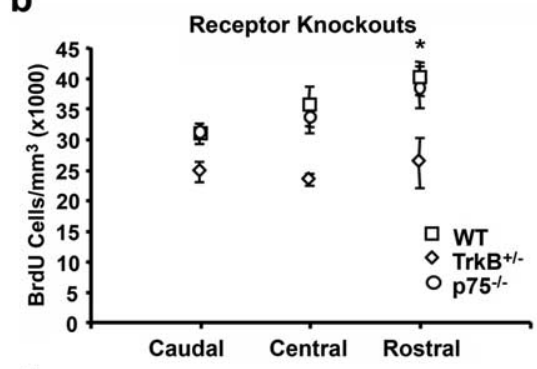

d

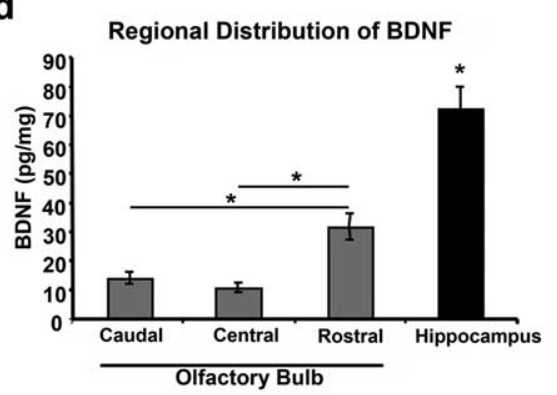

Figure 2. BDNF distribution and regional survival of newly born cells in the OB in BDNF and receptor mutant mice. $\boldsymbol{a}-\boldsymbol{c}$, Quantification of the density of surviving BrdU-positive cells $28 \mathrm{~d}$ after BrdU injection plotted by location within the olfactory bulb (caudal, central, rostral) of (a) BDNF ${ }^{+/+}$and BDNF ${ }^{+/-}$mice, $(\boldsymbol{b})$ WT, TrkB ${ }^{+/-}$, and p75 $5^{-1-}$ mice, and (c) BDNF ${ }^{+/+}$, $\mathrm{BDNF}^{+/ M}$, and BDNF ${ }^{\text {Met/Met }}$ mice. $\boldsymbol{d}$, Histogram depicting BDNF protein levels as assayed by ELISA for each of three regions of the OB (caudal, central, and rostral) as well as for the hippocampus. Statistical comparison for hippocampus relative to the olfactory bulb was with average BDNF levels across the three regions of the OB. Asterisks indicate statistically significant difference, ${ }^{*} p<0.05$.

of their location within the OB (rostral, central, or caudal) in mice of each genotype studied; i.e., $\mathrm{BDNF}^{+/+}$and $\mathrm{BDNF}^{+/-}$ mice (Fig. $2 a$ ); $75^{-l-}$, TrkB ${ }^{+/-}$, and wild-type mice (Fig. $2 b$ ); as well as $\mathrm{BDNF}^{+/+}, \mathrm{BDNF}^{+/ \mathrm{Met}}$, and BDNF ${ }^{\text {Met/Met }}$ mice (Fig. $2 c$ ). We found the greatest difference in the density of surviving cells for $\mathrm{BDNF}^{+/-}, \mathrm{TrkB}^{+/-}, \mathrm{BDNF}^{+/ \mathrm{Met}}$ and $\mathrm{BDNF}^{\mathrm{Met} / \mathrm{Met}}$ mice to be in the rostral $\mathrm{OB}$, a result consistent with a migratory defect related to altered BDNF-TrkB signaling. Loss of p75 did not appear to influence the distribution of surviving cells within the OB.

As previous reports of BDNF-mediated cerebellar development suggest that BDNF-mediated cellular migration is dependent on a standing gradient of BDNF (Zhou et al., 2007), we investigated the distribution of $\mathrm{BDNF}$ protein along the rostrocaudal axis of the OB via ELISA. We found that BDNF protein levels were significantly lower in the OB than in the hippocampus $\left(t\right.$ test, $\left.t_{(8)}=6.680, p<0.001\right)$. We also found a significant effect of location for BDNF protein distribution in the OB (ANOVA, $\left.F_{(2,12)}=23.152, p<0.001\right)$, with the highest levels of BDNF being found in the rostral extent (Fig. $2 d$ ). No differences in the level of BDNF protein were observed between the central or caudal portion of the OB. These results support the existence of a standing BDNF gradient along the rostrocaudal axis of the olfactory bulb that may regulate the migration of new neurons. In addition, we observed a significant reduction in BDNF protein levels within the $\mathrm{OB}$ of BDNF ${ }^{\mathrm{Met} / \mathrm{Met}}$ mice compared with wild-type controls (supplemental Fig. 1, available at www.jneurosci.org as supplemental material). One possible reason for the observed decrease in $\mathrm{BDNF}$ in mice that carry the $\mathrm{BDNF}_{\mathrm{Met}}$ allele could be because of the $\mathrm{OB}$ receiving the majority of its BDNF from projection neurons from cortical or other brain regions; however, it cannot be excluded that the $\mathrm{BDNF}_{\mathrm{Met}}$ allele might impact BDNF production in the OB. As a control, we noted no differences in total $\mathrm{BDNF}$ levels in the cortex of $\mathrm{BDNF}^{\mathrm{Met} / \mathrm{Met}}$ mice compared with wild-type controls (supplemental Fig. 1, available at www. jneurosci.org as supplemental material), consistent with previous work assaying BDNF levels from brain lysates from these same lines of mice (Chen et al., 2006).

As an additional test to investigate whether alterations in the regulated release of BDNF is involved in the migration of neuroblasts, we conducted a study in which we assessed the density of BrdUpositive cells $6 \mathrm{~d}$ after BrdU injection. This time course should have been optimal for estimating both the density of migrating neuroblasts as well as their location in the rostral migratory stream (RMS) after cell division but before cell differentiation (Winner et al., 2002). Consistent with a role for $\mathrm{BDNF}$ in cell migration and not survival, we found no main effect of genotype (repeated-measures ANOVA, $F=$ 5.725, $p<0.054$; e.g., no difference between genotypes in the total density of BrdU labeled cells in the RMS). We did find a significant genotype by section interaction (repeated-measures ANOVA, $F=6.698, p<0.003$ ), where BDNF wildtype mice had the majority of BrdUpositive cells localized near the anterior portion of the RMS, whereas BDNF ${ }^{\text {Met/Met }}$ mice had the majority of BrdU cells localized closer to the SVZ (supplemental Fig. 2, available at www. jneurosci.org as supplemental material).

\section{Immunohistochemical localization of activated TrkB receptors in neurogenic zones}

These studies of genetically modified lines of mice provide evidence that activity- dependent secretion of BDNF and TrkB receptors are critical for the survival of newly born cells in the OB. To determine whether BDNF-TrkB signaling is required during the migratory or differentiation process of neuroblasts, we took advantage of a recently developed phospho-specific TrkB receptor antibody that selectively recognizes the activated form of the TrkB receptor (pTrkB). The antibody was made against a phosphopeptide spanning the PLC- $\gamma$ site at Y816. Western blot analysis of the affinity-purified antibody showed that it specifically recognized the activated TrkB receptor in 293 cells stably overexpressing TrkB receptors (Narisawa-Saito et al., 2002) as well as in cultured hippocampal neurons (Fig. $3 a$ ). Specificity for the phosphorylated form of TrkB receptor was confirmed using peptide competition assays. The phosphopeptide effectively blocked binding of the pTrkB antibody to immunoblots from BDNFtreated 293-TrkB cell lysates (Fig. 3a). This antibody did not recognize activated TrkA receptors in PC12 cells or other tyrosine phosphorylated proteins (data not shown).

To assess the level of endogenous activated TrkB receptors in neurogenic regions in the intact animal, we conducted labeling studies in the adult mouse brain. The highest levels of pTrkB receptor labeling in the adult brain was found in densely packed proliferating and migrating precursor cells in the SVZ, RMS, and subependymal layer of the OB (selOB) (Fig. 3b) with relatively low levels of pTrkB labeling in mature regions of the olfactory bulb, further supporting a role for BDNF in neuroblast migration. Specificity of labeling was confirmed through peptide competition assays and analysis of labeling in $\operatorname{TrkB}^{+/-}$mice. In the 
a

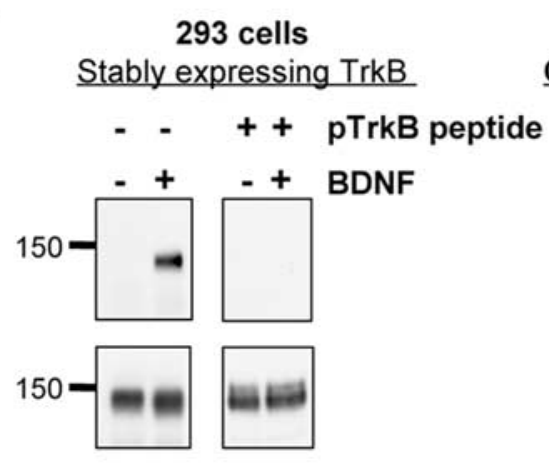

\section{Cultured Hc Neurons}

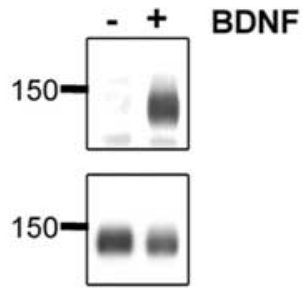

b
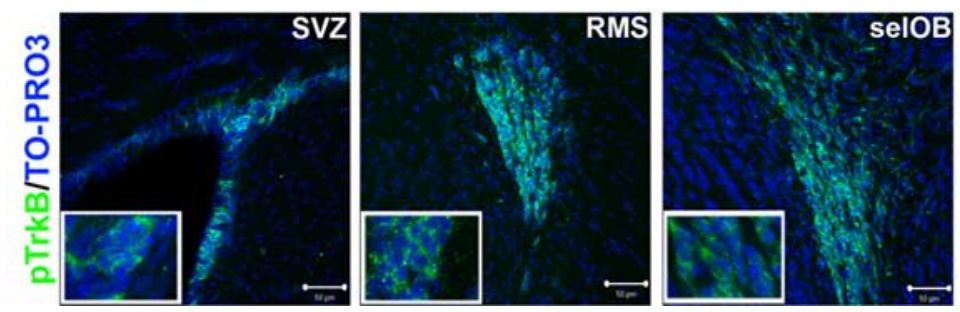
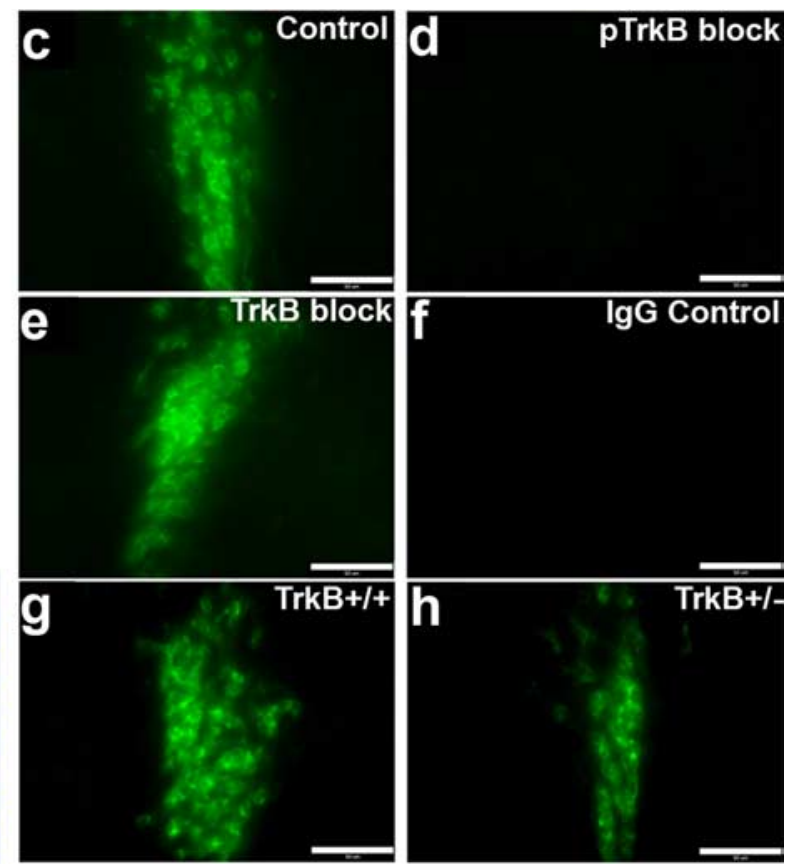

Figure 3. Specificity of phosphorylated TrkB receptor antibodies. Affinity purification of polyclonal antibodies raised against a short peptide in the C-terminal region of rat TrkB containing tyrosine 816 , which is phosphorylated in response to BDNF, was performed as described in Materials and Methods. $\boldsymbol{a}$, To assess specificity of purified antibodies, lysates (40 $\mu \mathrm{g}$ each well) obtained from 293 cells (left) stably expressing TrkB receptors and cultured hippocampal neurons (right) treated with $50 \mathrm{ng} / \mathrm{ml}$ BDNF for 10 min were probed with affinity-purified serum as well as purified sera that was preincubated with a phosphorylated TrkB peptide competitor. $\boldsymbol{b}$, Confocal images of phospho-TrkB receptor antibody-labeled cells within the SVZ, RMS, and selOB counterstained with T0-PRO3 (blue). $\boldsymbol{c}-\boldsymbol{f}$, Specificity of pTrkB receptor immunofluorescent labeling of cells in the RMS was determined with pTrkB alone (c) or in presence of phosphorylated (pTrkB) peptide (d), or nonphosphorylated (TrkB) peptide $(\boldsymbol{e})$, and with IgG control alone $(\boldsymbol{f}) . \boldsymbol{g}, \boldsymbol{h}$, Specificity of pTrkB receptor immunofluorescent labeling of cells in the RMS was further confirmed by the comparison of labeling in the RMS of TrkB ${ }^{+/+}(\boldsymbol{g})$ and TrkB ${ }^{+/-}$mice $(\boldsymbol{h})$. Scale bars, $100 \mu \mathrm{m}$.

RMS, control labeling (Fig. 3c) was compared with a peptide blocking condition using the phosphorylated TrkB peptide, which completely blocked labeling (Fig. $3 d$ ). We found no effect on immunoreactivity when blocking was performed with the nonphosphorylated TrkB peptide (Figs. 3e). In addition, we found no labeling in the IgG control condition (Fig. $3 f$ ). In $\mathrm{TrkB}^{+/-}$mice, we found a marked decrease in the level of pTrkB labeling in the RMS, with $\operatorname{TrkB}^{+/-}$mice having qualitatively fewer immunopositive cells than was observed in wild-type controls (Figs. $3 g, h$ ). Control immunolabeling was not possible in full TrkB null mice, as loss of TrkB during embryonic development results in lethality.

\section{Activated TrkB receptors are localized to type A migrating neuroblasts}

The SVZ and RMS contain a heterogeneous population of cells, composed of astrocyte quiescent neural progenitors (type B cells), actively proliferating precursors (type C cells), migrating neuroblasts (type A cells), ependymal cells (type E cells), and partially differentiated neural and glial cells (supplemental Fig. 3, available at www.jneurosci.org as supplemental material). To identify the cell type expressing the activated TrkB receptors in proliferative zones, we colabeled these neurogenic regions with pTrkB and a series of cell markers specific to the various neurogenic subtypes (dividing, migrating, differentiated, and support cells). In the RMS, pTrkB receptors were not detected on GFAP positive cells, a marker that labels type B glial precursor cells (Fig. $4 a)$ or on nestin positive cells $(b)$, which label actively mitotic type $\mathrm{C}$ cells. We found pTrkB receptors to be highly expressed on DCX- as well as PSA-NCAM-positive cells, (Fig. 4c,d), markers specific for actively migrating neuroblasts (type A cells). In addition, we found no overlap between pTrkB and isolectin B-4 an endothelial cell marker (Fig. 4e). Finally, pTrkB receptors were also not expressed on NeuN positive cells (Fig. $4 f$ ), a marker of neuronal nuclei. Analyses of the SVZ were also conducted using these same markers, and yielded an identical pattern of overlap (data not shown).

\section{p75 receptors are localized to a subset of proliferative type $C$} precursor cells

The p75 neurotrophin receptor has previously been shown to be expressed on nestin positive type $C$ cells in proliferative zones of the adult brain (Giuliani et al., 2004). Using immunolabeling and confocal microscopy, we first found that p75 receptors do not colocalize with pTrkB (Fig. $4 g$ ), and are expressed on a small proportion of cells within the SVZ, RMS, and selOB (Fig. $5 a-c$ ). Using double-immunofluorescent labeling in the RMS, p75 receptors did not localized to GFAP positive type B cells (Fig. $5 d$ ). In line with previous reports, we did find p75 receptors to be expressed on a subset of nestin and Ki-67 positive type C cells (Fig. 5e,f). In further analyses, p75 receptors were not expressed on doublecortin positive type A cells (Fig. $5 g$ ) or on isolectin B-4-positive endothelial cells (Fig. 5h). Finally, p75 receptors were also expressed on fibers surrounding NeuN positive cells (Fig. 5i). To assess the impact of loss of p75 on olfactory bulb morphometry, we measured the olfactory bulb volume of p75 null and wild-type mice. We found no difference in total OB or granule cell volume in $\mathrm{p} 75$ null mice despite detecting differences in the volume of both of these structures in BDNF ${ }^{\text {Met/Met }}$ mice relative to wild-type controls (supplemental Fig. 4, available at www.jneurosci.org as supplemental material). To ensure that p75 was completely absent, we assayed p75 immunoreactivity in the basal forebrain of $\mathrm{p} 75^{-1-}$ and wild-type controls and mice and found a complete loss of immunoreactivity in p75 null brains 

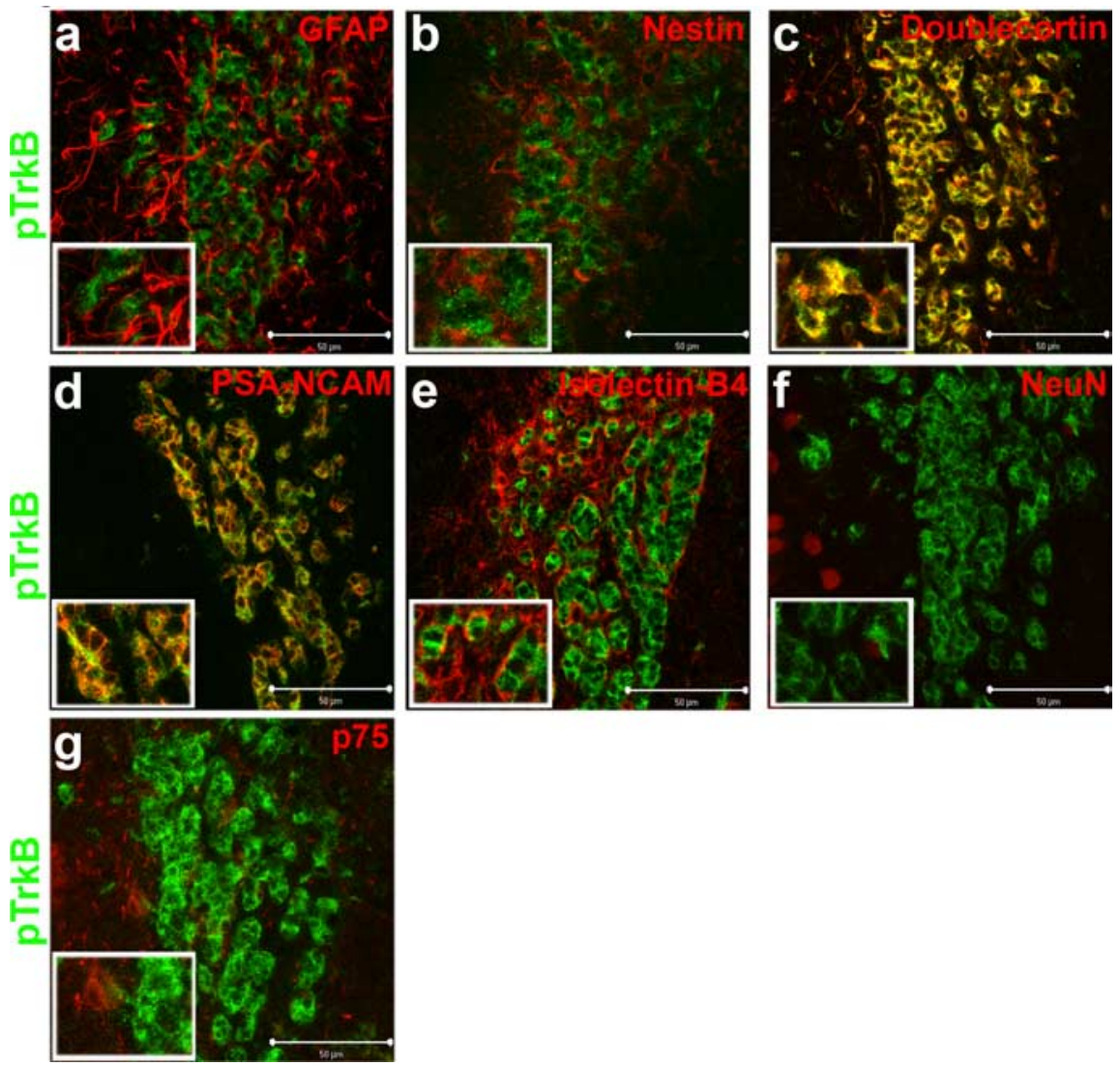

Figure 4. Activated TrkB receptors are highly localized to migrating neuroblasts (type A cells). $\boldsymbol{a}-\boldsymbol{g}$, Confocal optical sections were taken, at $63 \times$ magnification, of coronal slices of the mouse RMS immunolabeled for pTrkB receptors (green) and coimmunolabeled for markers of the various cell types composing the RMS. Top, Representative coronal sections of the RMS coimmunolabeled for pTrkB (green) and GFAP ( $\boldsymbol{a}$; red), Nestin ( $\boldsymbol{b}$; red), and doublecortin ( $\boldsymbol{c}$; red). Center panels display representative coronal sections of the RMS coimmunolabeled for pTrkB (green) and PSA-NCAM (d; red), isolectin B-4 (e; red), and NeuN (f; red). Bottom, Representative coronal section of pTrkB (green) coimmunolabeled with p75 (g; red). Scale bars, $50 \mu \mathrm{m}$.

(supplemental Fig. 5, available at www.jneurosci.org as supplemental material).

\section{Activity-dependent BDNF secretion is required for TrkB activation}

Previous studies have found that both BDNF and TrkB are highly localized to the SVZ (Zigova et al., 1998; Pencea et al., 2001), which is consistent with the observed high levels of activated TrkB in the SVZ, RMS, and selOB (Fig. 3b). However, to determine whether BDNF is the ligand responsible for the observed high levels of phosphorylated TrkB, we localized by immunohistochemistry BDNF within these regions, and conducted double labeling with pTrkB. BDNF was found to be highly localized in regions surrounding proliferative precursor cells in the SVZ, RMS, and selOB (Figs. $6 a-c$ ). Based on immunofluorescent double labeling, we found a high degree of overlap between BDNF and pTrkB receptors (Fig. $6 d-f$ ), with BDNF labeling accumulated as puncta surrounding $\mathrm{p}$ TrkB positive cells (Fig. $6 f$, inset). These results demonstrate that BDNF is properly localized to be the ligand responsible for $\operatorname{TrkB}$ receptor activation on migrating neurogenic type A precursor cells.

To determine whether activity-dependent BDNF secretion is required for this observed $\operatorname{TrkB}$ activation, SVZ regions were dissected from wild-type and secretion deficient BDNF ${ }^{\text {Met/Met }}$ mice, and phosphorylated TrkB levels were assayed by Western blot analysis. In these SVZ tissues from BDNF ${ }^{\text {Met/Met }}$ mice, there was a significant decrease in $\mathrm{pTrkB}$, compared with wild-type controls (Fig. 6g). Quantification of the SVZ pTrkB levels indicated that there was a $31 \pm 9.1 \%$ decrease (Student's $t$ test, $t_{(8)}=2.19, p<$ 0.03 ) in $\mathrm{BDNF}^{\mathrm{Met} / \mathrm{Met}}$ mice. This level of alteration in TrkB activation is consistent with previous findings that neurons from these mice have $\sim 30 \%$ decrease in activity-dependent BDNF secretion (Chen et al., 2006).

\section{Secretion-deficient BDNF Val66Met and haploinsufficient TrkB or BDNF mice exhibit deficits in spontaneous olfactory discrimination}

Previous studies have demonstrated that a reduction in the number of newly generated granule cell interneurons results in impairments in spontaneous olfactory discrimination (Gheusi et al., 2000). To assess the functional impact of decreased BDNF bioavailability on olfactory function, we used a spontaneous olfactory discrimination task in a set of genetically altered mice with reduced total BDNF levels, reduced levels of TrkB expression, or a selective defect in activity-dependent BDNF secretion. This task uses cross-habituation to measure the spontaneous behavioral differentiation among similar odorants, unaltered by associative learning or a history of reinforcement (Gheusi et al., 2000; Cleland et al., 2002; Linster et al., 2002). Mice were repeatedly presented with a single habituation odorant over four trials, during which the interest of the mice in the odorant was assessed by measuring investigation time. A progressive reduction in investigation time over consecutive trials represents a normal habituation response. Subsequently, the mice were presented with three test odorants that differed in their structural and perceptual similarity to the habituation odorant ( $S 1$, similar; S2, moderately similar; D, dissimilar) in a counterbalanced order, with the experimenter blind to genotype and odor stimulus. Spontaneous olfactory discrimination was measured by the change in investigation time during each of these test trials with respect to the last habituation trial; increases in investigation time represented a spontaneous differentiation between the test and the habituation and test odorants. This task was repeated using five different odor sets on separate days to increase statistical confidence; all data were combined before statistical analysis (supplemental Table 1, available at www.jneurosci.org as supplemental material).

We first tested BDNF haploinsufficient mice $\left(\mathrm{BDNF}^{+/-}\right)$, which express steady-state BDNF levels 50\% lower than those of wild-types (Ernfors et al., 1994). Both $\mathrm{BDNF}^{+/-}$and wild-type littermate control $\left(\mathrm{BDNF}^{+/+}\right)$mice investigated the habituation odorant progressively less over the four sequential presentations, indicating normal habituation (Wilks' $\lambda, F_{(3,66)}=26.038, p<$ $0.001)$. No differences between genotypes in the rate or degree of habituation were found $\left(F_{(1,68)}=0.059, p>0.05\right)$ (Fig. $7 a$ ). However, $\mathrm{BDNF}^{+/-}$mice differed from wild-type controls in their spontaneous discrimination performance, failing to differ- 
entiate between the habituation odorant and even the most dissimilar of the test odorants (simple effects analysis; $F_{(3,272)}=$ $0.389, p>0.05)$, whereas $\mathrm{BDNF}^{+/+}$mice spontaneously differentiated among test odorants $\left(F_{(3,272)}=4.518, p<0.01\right)$, significantly discriminating dissimilar odorants D from their corresponding habituation odorants (Tukey HSD, $p<0.05$ ) (Fig. $7 b$ ).

To confirm that the behavioral effects of BDNF signaling were mediated via TrkB receptors, we investigated whether similar behavioral impairments were also present in TrkB haploinsufficient mice $\left(\operatorname{TrkB}^{+/-}\right)$. Both $\operatorname{TrkB}^{+/-}$and wild-type littermate control $\left(\operatorname{TrkB}{ }^{+/+}\right)$mice investigated the habituation odorant progressively less over the course of the four sequential presentations, indicating normal habituation (Wilks' $\lambda, F_{(3,61)}=10.425, p<0.001$ ) (Fig. $7 c)$, although the two genotypes differed significantly in their overall habituation profiles $\left(F_{(1,63)}=4.355, p<0.05\right)$. $\mathrm{TrkB}^{+/-}$mice differed from wild-type controls in their spontaneous discrimination performance, failing to differentiate between the habituation odorant and even the most dissimilar of the test odorants (simple effects analysis, $F_{(3,128)}=0.615$, $p>0.05)$, whereas wild-type $\operatorname{TrkB}^{+/+}$ mice spontaneously differentiated among test odorants $\left(F_{(3,124)}=4.753, p<0.01\right)$, significantly discriminating dissimilar odorants D from their corresponding habituation odorants (Tukey HSD, $p<0.01$ ) (Fig. 7d).

BDNF can exert its biological effects through either constitutive or activity-dependent secretion (Lessmann et al., 2003; Nagappan and $\mathrm{Lu}, 2005)$. To assess the effects of activity-dependent secretion of BDNF on spontaneous olfactory discrimination, we repeated this behavioral task using mice carrying either a single $\left(\mathrm{BDNF}^{+/ \mathrm{Met}}\right)$ or two copies $\left(\mathrm{BDNF}^{\mathrm{Met} / \mathrm{Met}}\right)$ of the Met allele. Mice of all genotypes habituated normally to the repeated presentation of the habituation odorant (Wilks' $\lambda, F_{(3,108)}=41.797$, $p<0.001$ ), with no measurable difference between genotypes $\left(F_{(2,110)}=1.620, p>0.05\right)$ (Fig. $\left.7 e\right)$. Analysis of their spontaneous discrimination performance, however, revealed a significant main effect of genotype $\left(F_{(2,110)}=5.068, p<0.01\right)$, as well as a genotype by dissimilarity interaction (Wilks' $\lambda, F_{(6,216)}=3.260$, $p<0.01)$ indicating that the Met allele significantly influenced the ability of these mice to spontaneously discriminate similar odorants. Post hoc analyses showed that both $\mathrm{BDNF}^{+/ \mathrm{Met}}$ and $\mathrm{BDNF}^{\mathrm{Met} / \mathrm{Met}}$ mice discriminated test odorants significantly more poorly than did wild-type mice (Tukey HSD, $p>0.05$ in both cases). Whereas the $\mathrm{BDNF}^{+/ \mathrm{Met}}$ and $\mathrm{BDNF}^{\mathrm{Met} / \mathrm{Met}}$ mice failed to discriminate among any of the test odorants presented, $\mathrm{BDNF}^{+/+}$(wild-type) mice differentiated normally among test odorants (simple effects analysis, $F_{(3,440)}=10.286, p<0.001$ ), showing a significantly increased interest in odorants S2 (Tukey HSD, $p<0.01)$ and D $(p<0.001)$ compared with the habituation odorant (Fig. $7 f$ ).

\section{Discussion}

In this report, we provide evidence that activity-dependent secretion of BDNF and TrkB receptor activation are critical for endogenous control of neurogenesis. This is supported through immunohistochemical analyses, where we demonstrated high levels of BDNF surrounding migrating neuroblasts (type A cells) that expressed phosphorylated TrkB. Consistent with those data, $\mathrm{BDNF}^{\mathrm{Met} / \mathrm{Met}}$ mice had reduced levels of TrkB phosphorylation in the germinal zone, altered migration of neuroblasts within the RMS, and region-specific impairments in survival of newly born cells in the $\mathrm{OB}$, all indicative of a migration defect. In our behavioral analyses of $\mathrm{BDNF}^{\mathrm{Met} / \mathrm{Met}}$ mice, a model for the human BDNF Val66Met polymorphism, we identified a specific impairment in spontaneous olfactory discrimination, the first delineation of an olfactory behavioral deficit in genetically modified neurotrophin mice. As loss of neurotrophin signaling does not impact olfactory system development (Nef et al., 2001), we propose that the observed behavioral deficit in olfaction is linked to impaired neurogenesis. These findings, although correlational, identify BDNF as critical for normal functioning of the olfactory system potentially through its regulation of the migration and survival of the largest population of newborn neurons in the adult brain.

As BDNF and its receptors, TrkB and p75, are expressed in the adult SVZ, and the administration or overexpression of exoge- 

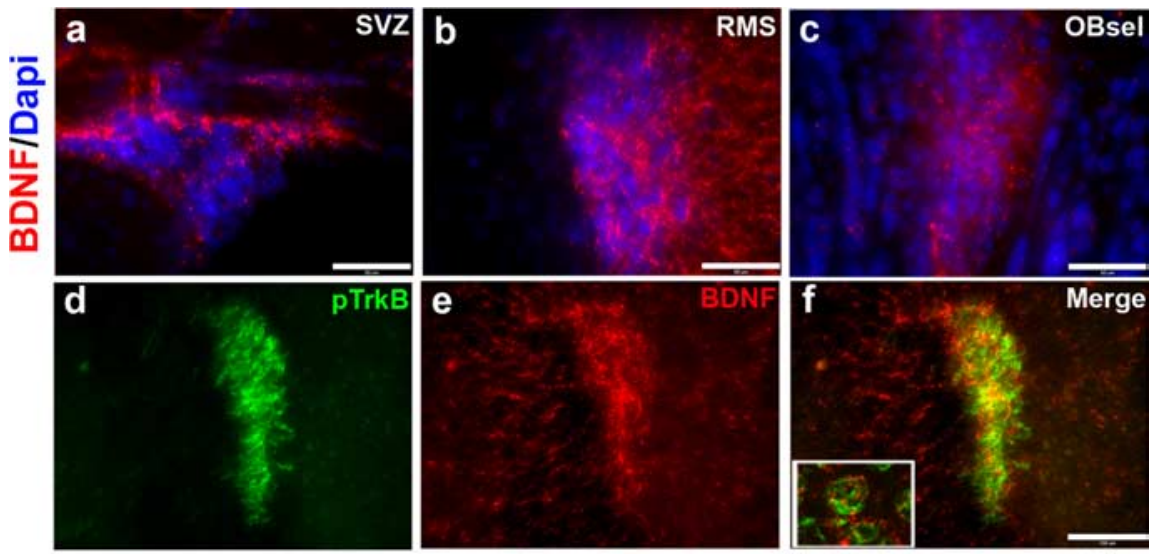

Merge

g $+1+$

Met/Met

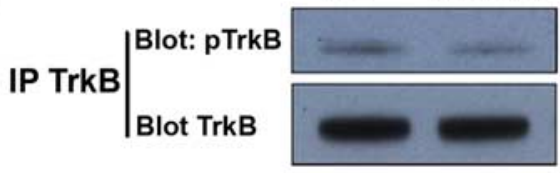

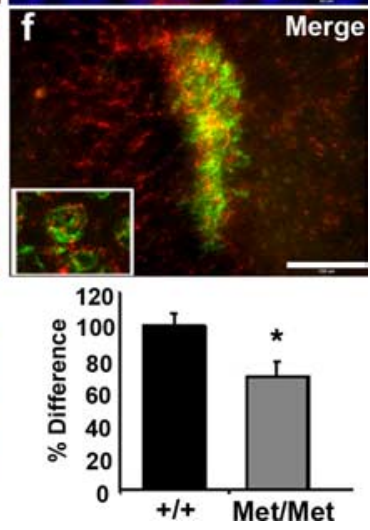

Figure 6. BDNF and pTrkB immunoreactivity in neurogenic regions. Optical sections were taken at $40 \times$ magnification of coronal slices of the mouse SVZ $(\boldsymbol{a})$, RMS $(\boldsymbol{b})$, and selOB $(\boldsymbol{c})$, immunolabeled for BDNF (red) and counterstained with DAPI (4,6,diamidino-2-phenylindole; blue). Scale bars, $50 \mu \mathrm{m}$. Middle, Representative coronal sections of the mouse RMS taken at $20 \times$ magnification and coimmunolabeled for pTrkB receptor $(\boldsymbol{d}), \operatorname{BDNF}(\boldsymbol{e})$, and merged $(\boldsymbol{f})$. Included is an inset from confocal imaging of this same section showing BDNF to be highly localized surrounding pTrkB positive cells. Scale bars, $100 \mu \mathrm{m} . \boldsymbol{g}$, Bottom, Representative immunoblots from intraperitoneal Westerns blotted for pTrkB and subsequently for total TrkB proteins in SVZ tissue, as well as quantification of percentage difference in the percentage activated TrkB corrected for total TrkB levels. Quantification is presented as percentage difference from wild-type density, with error bars depicting SEM. Asterisk indicates statistically significant difference (Student's $t$ test, ${ }^{*} p<0.05$ ).

nous BDNF alters rates of neurogenesis (Zigova et al., 1998; Benraiss et al., 2001; Pencea et al., 2001), BDNF has been implicated as a potentially critical signaling molecule controlling endogenous rates of neurogenesis. Using genetically engineered mice, we have shown that BDNF and TrkB receptors are critical for cell migration and survival in adult $\mathrm{OB}$ neurogenesis but not cell proliferation. Activated TrkB receptors were highly expressed in migrating neuroblasts and loss of BDNF signaling resulted in region-specific impairments in cell survival within the RMS and OB. From these data, we conclude that BDNF likely plays an important role in neuroblast migration. This interpretation is consistent with recent reports identifying BDNF-TrkB signaling as critical for SVZ derived neuroblast migration in vitro (Chiaramello et al., 2007). Our data are suggestive of an active role for BDNF signaling in the process of chemotaxis, but an additional role for BDNF in promoting survival during neuroblast migration cannot be excluded. It also remains to be determined whether the high levels of $\mathrm{p} \operatorname{TrkB}$ receptor labeling in neuroblasts represents the full complement of activated TrkB receptors, or merely a subset, as the antibody detects only one TrkB receptor phosphorylation site (Y816), a site shown to be critical for appropriate migration and stratification of cortical precursor cells (Medina et al., 2004). Our findings, that BDNF-TrkB signaling is important for adult neurogenesis, is also consistent with previous studies in the developing cerebellum and cortex where BDNF functions in chemotaxis, regulates attachment of neuroblasts to radial glia, and facilitates neuroblast migration from germinal zones to mature structures in a p75-independent process (Behar et al., 1997; Borghesani et al., 2002, Zhou et al., 2007). Previously, the migration of neuroblasts has been shown to depend on neurotransmission among cells, such as the activation of cholinergic synapses existing on migrating precursor cells (Kaneko et al.,
2006) or through nonsynaptic GABAergic signaling (Platel et al., 2007). Either the release of BDNF from en passant synapses or endogenously produced BDNF from neuroblasts could serve as the mechanism by which BDNF mediates its effects on $\mathrm{OB}$ neurogenesis in an activity dependent manner. Currently, we cannot conclusively localize the source of BDNF regulating neurogenesis (e.g., if BDNF from neuroblasts or projection neurons is the source). Furthermore, because of difficulty in selectively harvesting adequate numbers of actively migrating cells, we cannot demonstrate that the secretion defect found in cortical neurons of BDNF Val66Met mice is also present in neuroblasts.

Consistent with previous reports, p75 receptor were expressed in a subpopulation of cells within the proliferative zone (Giuliani et al., 2004), nestin and Ki-67 positive type $C$ cells (Fig. $5 E$ and $5 F$ ). p75 receptors have been shown to be involved in regulating cell survival and cell death decisions (Chao, 2003), and may serve this functional purpose in postmitotic cells. However, in our studies of $\mathrm{p} 75^{-1-}$ mice, we found no change in the density of surviving newly born cells in the olfactory bulb or alteration in olfactory bulb volume. Thus, any functional role of p75 receptors in SVZ neurogenesis has yet to be identified.

A compelling question surrounding adult neurogenesis has been whether it serves a functional purpose. In the OB, rates of neurogenesis have been highly correlated with olfactory performance on a spontaneous olfactory discrimination task (Gheusi et al., 2000). Such findings are strengthened by work demonstrating that olfactory enrichment increases rates of neurogenesis and improves olfactory performance, whereas deprivation reduces both concomitantly (Mandairon et al., 2003, 2006a; Saghatelyan et al., 2005). In those studies, the behavioral effects were all attributed to alterations in the number and distribution of granule cells (Lledo and Gheusi, 2003; Lledo et al., 2004), the cell type into which nearly $95 \%$ of neurogenic cells differentiate (Winner et al., 2002). The impairments in spontaneous olfactory discrimination and effect sizes observed in $\mathrm{BDNF}^{+/-}, \operatorname{TrkB}^{+/-}$, and $\mathrm{BDNF}^{\mathrm{Met} / \mathrm{Met}}$ mice are consistent with findings in animals in which newly born granule cells are lost (Gheusi et al., 2000). Although the finding from this current study provide strong correlational evidence for a role for newly born cells in olfactory discrimination, future studies in which cell specific excision of BDNF or its receptor, TrkB, will be required to directly link these discrimination defects to the loss of newborn cells and eliminate the possibility of any secondary effects of BDNF on olfactory function.

The loss of neurotrophins leads to impairments in peripheral neuron development and axonal targeting to chemosensory organs such as the tongue (Ringstedt et al., 1993; Lopez and Krimm, 2006). However, OB organization, axonal targeting, and epithelial development are all unimpaired in BDNF and TrkB receptor knock-out mice (Nef et al., 2001). Decreased BDNF levels have been proposed to have secondary effects in regulating axonal 
competition in the OB (Cao et al., 2007). In this recent report, using an independently developed BDNFVal66Met knockin mouse line, the authors found that the $\mathrm{BDNF}_{\mathrm{Met}}$ mutation alone had no effect on olfactory sensory neuron axon morphology. Only when the BDNFVal66Met mice were crossed with mice lacking efficient synaptic vesicle release (LF-TeTxLC) were alterations on axonal competition observed (Cao et al., 2007). BDNF is also highly expressed within the olfactory epithelia and can regulate neuronal excitability within olfactory regions (Fadool et al., 2004; Nanobashvili et al., 2005). Without regional control over BDNF or TrkB, we cannot exclude these as possibilities for the observed behavioral defects. However, as no differences were found in the ability of BDNFVal66Met mutant mice to detect, investigate, and habituate to an odor (Fig. $7 a, c)$, we suggest that their basic olfactory perceptual capacities remain intact, and attribute the impairments in spontaneous olfactory discrimination to impaired neurogenesis.

Neurogenesis in adulthood represents the remarkable and lifelong self-renewing capacity of the nervous system. We provide evidence that perturbations in $\mathrm{OB}$ neurogenesis are linked to impaired activitydependent secretion of BDNF. We further link these impairments in neurogenesis to significant and specific defects in the ability of the nervous system to detect and process changes in the environment. A major hurdle in understanding the in vivo function of adult neurogenesis has been an incomplete understanding of the molecular mechanisms regulating proliferation, migration, and differentiation of these cells. We provide converging lines of evidence here for a model by which secreted BDNF activates TrkB receptors in migrating neuroblasts, maintaining their survival or promoting their migration to their eventual destination in the OB. We then link disruption in this process through inefficient TrkB signaling with significant and specific impairments in olfactory function. These findings are compelling as this system provides a unique opportunity to further dissect the molecular mechanisms underlying how growth factor signaling in this population of regenerating cells in vivo leads to definable behavioral consequences.

The olfactory deficits in BDNF Val66Met mice have potential relevance for informing genetic studies of human disorders. First, this mouse has been validated as a model for the common human BDNF SNP (Val66Met), and has reproduced the phenotypic effects observed in human SNP carriers (Bath and Lee, 2006; Chen et al., 2006). With this mouse, it is possible to identify endophenotypes for disease processes in a substantially more controlled manner than is possible in human subject research. Second, olfactory discrimination deficits have been consistently observed in Error bars depict SEM. b
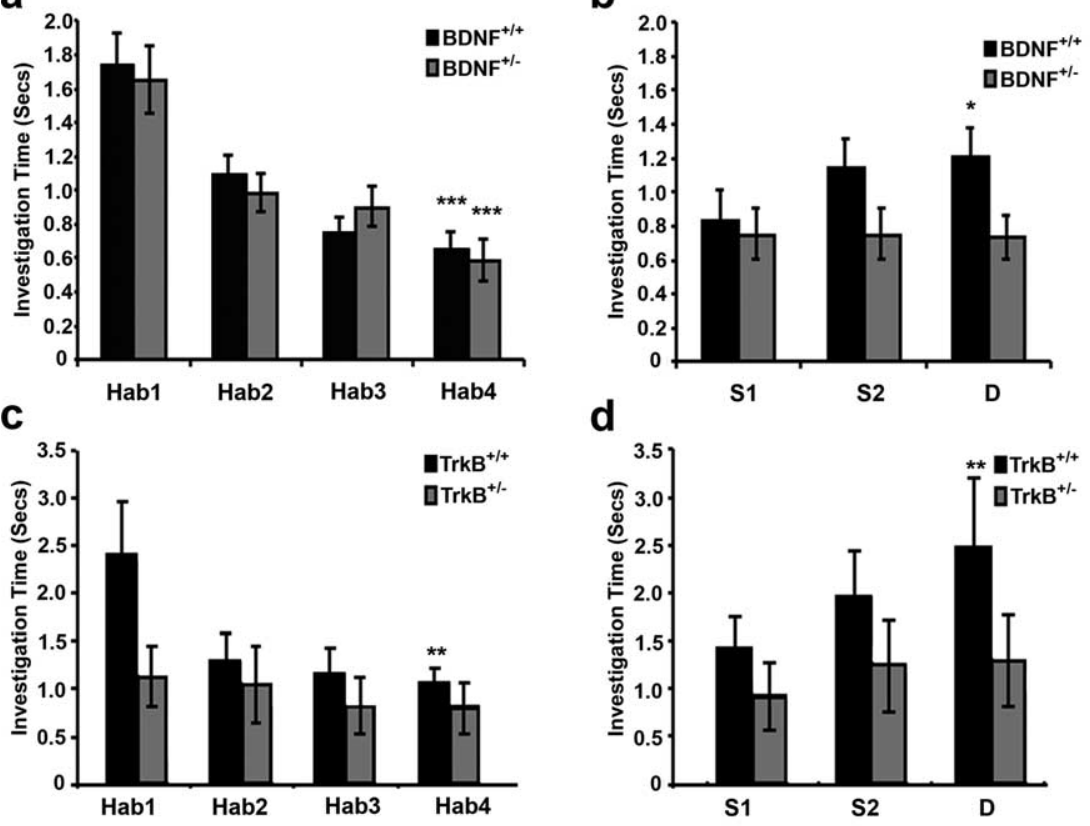

f

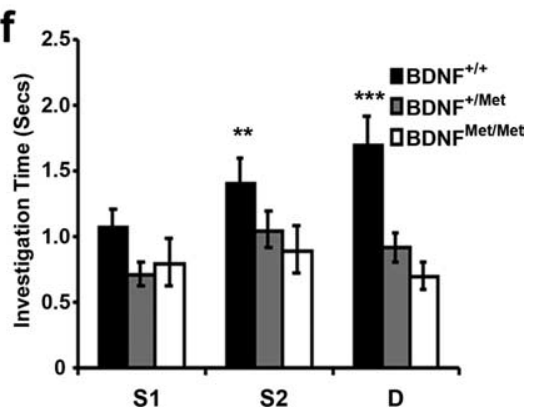

Figure 7. BDNFhaploinsufficient, TrkB haploinsufficient, and BDNF knock-in lines of mice do not spontaneously discriminate between odorants. Olfactory behavioral habituation and cross-habituation data in BDNF knock-out, TrkB knock-out, and BDNF knock-in lines of mice (spontaneous discrimination). $a$, Habituation profiles for BDNF ${ }^{+/+}(n=6)$ and BDNF $^{+/-}(n=6)$ mice (for odor sets, see supplemental Table 1, available at www.jneurosci.org as supplemental material), showing a significant reduction in investigation time across four repeated presentations of a habituation odorant (Hab). Asterisks indicate a highly significant difference $(p<0.001)$ in investigation time between trials Hab1 and Hab4. $\boldsymbol{b}$, Investigation times of test odorants increased for BDNF ${ }^{+/+}$(wild-type), but not BDNF ${ }^{+/-}$mice, as a function of odor similarity (S1, very similar; $S 2$, moderately similar; D, dissimilar). Asterisks indicate significance values, ${ }^{*} p<0.05$ between mice habituated normal, but TrkB ${ }^{+/-}$mice failed to habituation to repeated odorant presentations. Asterisks are as in $\boldsymbol{a}$, but indicating $p<0.01$. , Investigation times of test odorants increased for wild-type but not $\operatorname{TrkB}^{+/-}$mice as a function of odor similarity. TrkB ${ }^{+/-}$ dest odorants from the habituation odorant. Asterisks indicate a highly significant (BDNF $\left.^{+/ \text {Met }}, n=7\right)$ or two copies (BDNF $\left.{ }^{\text {Met/Met }}, n=7\right)$ of the BDNF Met allele are similar to those of wild-type littermates $\left(\right.$ BDNF $\left.^{+/+}, n=7\right)$. Asterisks are as in a.f, Investigation times of test odorants increased for BDNF ${ }^{+/+}$(wild-type) as a function of odor similarity, but BDNF ${ }^{\text {Met/Met }}$ and BDNF ${ }^{+/ \text {Met }}$ mice failed to spontaneously discriminate any of the test odorants from the habituation odorant. Asterisks indicate significant differences $\left({ }^{* *} p<0.01\right.$; $\left.{ }^{* * *} p<0.001\right)$ in investigation times between Hab4 and the test odor.

the progression of certain neuropsychiatric disorders (Mesholam et al., 1998; Malaspina and Coleman, 2003), and are considered as potential behavioral endophenotypes for these disorders. However, the mechanisms underlying the observed olfactory deficits are unknown. In this context, a migratory stream leading from the subventricular zone of the lateral ventricles to the olfactory bulb of humans has been identified (Curtis et al., 2007). Thus, our neurogenesis and behavioral findings related to the BDNF Val66Met SNP suggest one potential genetic model by which a discrete molecular alteration in the human BDNF gene may contribute to disease endophenotypes. 


\section{References}

Alonso M, Viollet C, Gabellec MM, Meas-Yedid V, Olivo-Marin JC, Lledo PM (2006) Olfactory discrimination learning increases the survival of adult-born neurons in the olfactory bulb. J Neurosci 26:10508-10513.

Altman J (1969) Autoradiographic and histological studies of postnatal neurogenesis. IV. Cell proliferation and migration in the anterior forebrain, with special reference to persisting neurogenesis in the olfactory bulb. J Comp Neurol 137:433-457.

Bath KG, Lee FS (2006) Variant BDNF (Val66Met) impact on brain structure and function. Cogn Affect Behav Neurosci 6:79-85.

Behar TN, Dugich-Djordjevic MM, Li YX, Ma W, Somogyi R, Wen X, Brown E, Scott C, McKay RD, Barker JL (1997) Neurotrophins stimulate chemotaxis of embryonic cortical neurons. Eur J Neurosci 9:2561-2570.

Benraiss A, Chmielnicki E, Lerner K, Roh D, Goldman SA (2001) Adenoviral brain-derived neurotrophic factor induces both neostriatal and olfactory neuronal recruitment from endogenous progenitor cells in the adult forebrain. J Neurosci 21:6718-6731.

Borghesani PR, Peyrin JM, Klein R, Rubin J, Carter AR, Schwartz PM, Luster A, Corfas G, Segal RA (2002) BDNF stimulates migration of cerebellar granule cells. Development 129:1435-1442.

Cao L, Dhilla A, Mukai J, Blazeski R, Lodovichi C, Mason CA, Gogos JA (2007) Genetic modulation of BDNF signaling affects the outcome of axonal competition in vivo. Curr Biol 17:911-921.

Chao MV (2003) Neurotrophins and their receptors: a convergence point for many signalling pathways. Nat Rev Neurosci 4:299-309.

Chen ZY, Jing D, Bath KG, Ieraci A, Khan T, Siao CJ, Herrera DG, Toth M, Yang C, McEwen BS, Hempstead BL, Lee FS (2006) Genetic variant BDNF (Val66Met) polymorphism alters anxiety-related behavior. Science 314:140-143.

Chiaramello S, Dalmasso G, Bezin L, Marcel D, Jourdan F, Peretto P, Fasolo A, De Marchis S (2007) BDNF/ TrkB interaction regulates migration of SVZ precursor cells via PI3-K and MAP-K signalling pathways. Eur J Neurosci 26:1780-1790.

Cleland TA, Narla VA (2003) Intensity modulation of olfactory acuity. Behav Neurosci 117:1434-1440.

Cleland TA, Morse A, Yue EL, Linster C (2002) Behavioral models of odor similarity. Behav Neurosci 116:222-231.

Curtis MA, Kam M, Nannmark U, Anderson MF, Axell MZ, Wikkelso C, Holtas S, van Roon-Mom WM, Bjork-Eriksson T, Nordborg C, Frisen J, Dragunow M, Faull RL, Eriksson PS (2007) Human neuroblasts migrate to the olfactory bulb via a lateral ventricular extension. Science 315:1243-1249.

Ernfors P, Lee KF, Jaenisch R (1994) Mice lacking brain-derived neurotrophic factor develop with sensory deficits. Nature 368:147-150.

Fadool DA, Tucker K, Perkins R, Fasciani G, Thompson RN, Parsons AD, Overton JM, Koni PA, Flavell RA, Kaczmarek LK (2004) Kv1.3 channel genetargeted deletion produces "Super-Smeller Mice" with altered glomeruli, interacting scaffolding proteins, and biophysics. Neuron 41:389-404.

Fukumitsu H, Ohtsuka M, Murai R, Nakamura H, Itoh K, Furukawa S (2006) Brain-derived neurotrophic factor participates in determination of neuronal laminar fate in the developing mouse cerebral cortex. J Neurosci 26:13218-13230.

Gheusi G, Cremer H, McLean H, Chazal G, Vincent JD, Lledo PM (2000) Importance of newly generated neurons in the adult olfactory bulb for odor discrimination. Proc Natl Acad Sci USA 97:1823-1828.

Giuliani A, D’Intino G, Paradisi M, Giardino L, Calza L (2004) p75(NTR)immunoreactivity in the subventricular zone of adult male rats: expression by cycling cells. J Mol Histol 35:749-758.

Kaneko N, Okano H, Sawamoto K (2006) Role of the cholinergic system in regulating survival of newborn neurons in the adult mouse dentate gyrus and olfactory bulb. Genes Cells 11:1145-1159.

Kirschenbaum B, Goldman SA (1995) Brain-derived neurotrophic factor promotes the survival of neurons arising from the adult rat forebrain subependymal zone. Proc Natl Acad Sci USA 92:210-214.

Lee FS, Chao MV (2001) Activation of Trk neurotrophin receptors in the absence of neurotrophins. Proc Natl Acad Sci USA 98:3555-3560.

Lee KF, Li E, Huber LJ, Landis SC, Sharpe AH, Chao MV, Jaenisch R (1992) Targeted mutation of the gene encoding the low affinity NGF receptor p75 leads to deficits in the peripheral sensory nervous system. Cell 69:737-749.

Lessmann V, Gottmann K, Malcangio M (2003) Neurotrophin secretion: current facts and future prospects. Prog Neurobiol 69:341-374.

Linster C, Johnson BA, Morse A, Yue E, Leon M (2002) Spontaneous versus reinforced olfactory discriminations. J Neurosci 22:6842-6845.
Lledo PM, Gheusi G (2003) Olfactory processing in a changing brain. NeuroReport 14:1655-1663.

Lledo PM, Saghatelyan A (2005) Integrating new neurons into the adult olfactory bulb: joining the network, life-death decisions, and the effects of sensory experience. Trends Neurosci 28:248-254.

Lledo PM, Saghatelyan A, Lemasson M (2004) Inhibitory interneurons in the olfactory bulb: from development to function. Neuroscientist 10:292-303.

Lopez GF, Krimm RF (2006) Epithelial overexpression of BDNF and NT4 produces distinct gustatory axon morphologies that disrupt initial targeting. Dev Biol 292:457-468.

Malaspina D, Coleman E (2003) Olfaction and social drive in schizophrenia. Arch Gen Psychiatry 60:578-584.

Mandairon N, Jourdan F, Didier A (2003) Deprivation of sensory inputs to the olfactory bulb upregulates cell death and proliferation in the subventricular zone of adult mice. Neuroscience 119:507-516.

Mandairon N, Stack C, Kiselycznyk C, Linster C (2006a) Enrichment to odors improves olfactory discrimination in adult rats. Behav Neurosci 120:173-179.

Mandairon N, Sacquet J, Garcia S, Ravel N, Jourdan F, Didier A (2006b) Neurogenic correlates of an olfactory discrimination task in the adult olfactory bulb. Eur J Neurosci 24:3578-3588.

Medina DL, Sciarretta C, Calella AM, Von Bohlen Und Halbach O, Unsicker K, Minichiello L (2004) TrkB regulates neocortex formation through the Shcl PLCgamma-mediated control of neuronal migration. EMBO J 23:3803-3814.

Mesholam RI, Moberg PJ, Mahr RN, Doty RL (1998) Olfaction in neurodegenerative disease: a meta-analysis of olfactory functioning in Alzheimer's and Parkinson's diseases. Arch Neurol 55:84-90.

Nagappan G, Lu B (2005) Activity-dependent modulation of the BDNF receptor TrkB: mechanisms and implications. Trends Neurosci 28:464-471.

Nanobashvili A, Jakubs K, Kokaia M (2005) Chronic BDNF deficiency permanently modifies excitatory synapses in the piriform cortex. J Neurosci Res 81:696-705.

Narisawa-Saito M, Iwakura Y, Kawamura M, Araki K, Kozaki S, Takei N, Nawa H (2002) Brain-derived neurotrophic factor regulates surface expression of alpha-amino-3-hydroxy-5-methyl-4-isoxazoleproprionic acid receptors by enhancing the N-ethylmaleimide-sensitive factor/GluR2 interaction in developing neocortical neurons. J Biol Chem 277:40901-40910.

Nef S, Lush ME, Shipman TE, Parada LF (2001) Neurotrophins are not required for normal embryonic development of olfactory neurons. Dev Biol 234:80-92.

Pencea V, Bingaman KD, Wiegand SJ, Luskin MB (2001) Infusion of brainderived neurotrophic factor into the lateral ventricle of the adult rat leads to new neurons in the parenchyma of the striatum, septum, thalamus, and hypothalamus. J Neurosci 21:6706-6717.

Platel JC, Lacar B, Bordey A (2007) GABA and glutamate signaling: homeostatic control of adult forebrain neurogenesis. J Mol Histol 38:303-311.

Rajagopal R, Chen ZY, Lee FS, Chao MV (2004) Transactivation of Trk neurotrophin receptors by G-protein-coupled receptor ligands occurs on intracellular membranes. J Neurosci 24:6650-6658.

Ringstedt T, Lagercrantz H, Persson H (1993) Expression of members of the trk family in the developing postnatal rat brain. Brain Res Dev Brain Res 72:119-131.

Saghatelyan A, Roux P, Migliore M, Rochefort C, Desmaisons D, Charneau P, Shepherd GM, Lledo PM (2005) Activity-dependent adjustments of the inhibitory network in the olfactory bulb following early postnatal deprivation. Neuron 46:103-116.

Winner B, Cooper-Kuhn CM, Aigner R, Winkler J, Kuhn HG (2002) Longterm survival and cell death of newly generated neurons in the adult rat olfactory bulb. Eur J Neurosci 16:1681-1689.

Xu B, Zang K, Ruff NL, Zhang YA, McConnell SK, Stryker MP, Reichardt LF (2000) Cortical degeneration in the absence of neurotrophin signaling: dendritic retraction and neuronal loss after removal of the receptor TrkB. Neuron 26:233-245.

Young KM, Merson TD, Sotthibundhu A, Coulson EJ, Bartlett PF (2007) p75 neurotrophin receptor expression defines a population of BDNFresponsive neurogenic precursor cells. J Neurosci 27:5146-5155.

Zhou P, Porcionatto M, Pilapil M, Chen Y, Choi Y, Tolias KF, BikoffJB, Hong EJ, Greenberg ME, Segal RA (2007) Polarized signaling endosomes coordinate BDNF-induced chemotaxis of cerebellar precursors. Neuron 55:53-68.

Zigova T, Pencea V, Wiegand SJ, Luskin MB (1998) Intraventricular administration of BDNF increases the number of newly generated neurons in the adult olfactory bulb. Mol Cell Neurosci 11:234-245. 